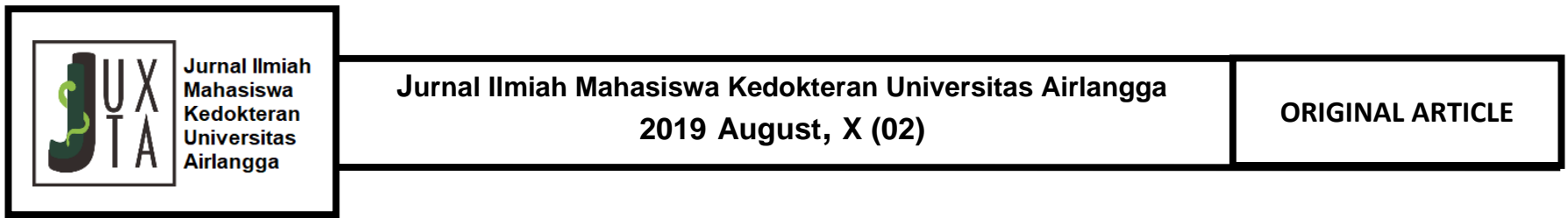

\title{
The Relationship between Early Initiation of Breastfeeding and Exclusive Breastfeeding in the Work Area of Wiyung Public Health Center, Surabaya
}

\author{
Vira Dwi Nisrina ${ }^{1}$, Sundari Indah Wiyasihati ${ }^{\star}{ }^{\star}$, Widati Fatmaningrum ${ }^{3}$, Sulistiawati ${ }^{3}$
}

${ }^{1}$ Faculty of Medicine, Universitas Airlangga, Surabaya, Indonesia.
${ }^{2}$ Department of Physiology, Faculty of Medicine, Universitas Airlangga, Surabaya, Indonesia.
${ }^{3}$ Department of Public Health and Preventive Medicine, Faculty of Medicine, Universitas Airlangga, Surabaya, Indonesia.

\section{A B S T R A C T}

Introduction: In Indonesia, there has been a 10\% increase in the span of five years for exclusive breastfeeding, however this is still far from the national target. One of the factors that can cause low rates of national exclusive breastfeeding is that not all babies have received an early initiation of breastfeeding. The purpose of this study was to determine the relationship between early initiation of breastfeeding and exclusive breastfeeding for babies aged 7-12 months in the work area of Wiyung Public Health Center, Surabaya.

Methods: This study was a quantitative research with a cross-sectional approach. The study used a questionnaire as the research instrument given to 30 respondents, namely mothers who had 7-12 month old babies in the work area of Wiyung Public Health Center, Surabaya.

Results: The percentage of early initiation of breastfeeding in babies aged 7-12 months was $53.33 \%$ meanwhile the percentage of exclusive was $73.33 \%$. Using Chi Square Fisher Exact Test, it was found that there is no relationship between early initiation of breastfeeding and exclusive breastfeeding for babies aged 7-12 months in the working area of the Wiyung Public Health Center in Surabaya. (The value of $p$ $=0.574$ with a value of $\alpha=0.05, p>\alpha$ ).

Conclusion: The early initiation of breastfeeding is not the only factor influencing exclusive breastfeeding for babies aged 7-12 months in the work area of the Wiyung Public Health Center in Surabaya. Further research is needed on other factors that can relate to and influence exclusive breastfeeding.

\footnotetext{
* Correspondence: sundari-i-w@fk.unair.ac.id
}

JUXTA: Jurnal IImiah Mahasiswa Kedokteran Universitas Airlangga

p-ISSN: 1907-3623; e-ISSN: 2684-9453

DOI: $10.20473 /$ juxta.V10I22019.48-50

Open access under Creative Commons Attribution-ShareAlike 4.0 International License (CC-BY-SA)

\section{ARTICLE INFO}

Article history:

Received 02 August 2019

Received in revised form 15 August 2019

Accepted 19 August 2019

\section{Keywords:}

Early initiation of breastfeeding,

Exclusive breastfeeding,

Surabaya,

Indonesia. 


\section{Introduction}

Breast milk is a liquid secretion from alveoli cells in the mother's breast glands that contain various kinds of substances that are important for the growth and development of the baby. The content in breast milk plays a role in the baby's immune system to prevent disease and has antibodies that are more effective when compared to formula milk. ${ }^{1}$ Exclusive breastfeeding means babies only consume breast milk as source of nutrition except medicines, vitamins, and mineral drops for 6 months after birth. ${ }^{2}$

There is an increasing tendency for exclusive breastfeeding in babies aged 0-6 months. The increase in the number of exclusive breastfeeding is $10 \%$, from $32 \%$ in 2007 to $42 \%$ in 2012 . Although there has been a $10 \%$ increase in the span of five years, this is still far from the national target on exclusive breastfeeding (80\%).

One of the factors that can cause low rates of national exclusive breastfeeding is that not all babies have received an early initiation of breastfeeding. ${ }^{3}$ Early initiation of breastfeeding means giving breast milk to the baby as soon as the baby is born by skin-to-skin contact, usually within 30 minutes to 1 hour after the baby is born. ${ }^{4}$ The babies who are given the opportunity to breastfeed early will be eight times more successful in exclusive breastfeeding, meanwhile delaying the onset of breastfeeding more than one hour will cause difficulty in breastfeeding. ${ }^{5}$ National data showed that early initiation of breastfeeding had increased from $29.3 \%$ (in 2010) to $34.5 \%$ (in 2013). ${ }^{6}$

There are similar studies which results showed that there was no relationship between early initiation of breastfeeding and exclusive breastfeeding, whereas on the contrary some studies found that there was a relationship between early initiation of breastfeeding and exclusive breastfeeding. ${ }^{7-9}$ Further research is needed to find out the relationship between early initiation of breastfeeding and the successful implementation of exclusive breastfeeding for babies aged 712 months so it can be used as an additional reference and educational material to make people aware of the importance of early initiation of breastfeeding for maternal and baby health while increasing the national exclusive breastfeeding rate.

\section{Methods}

This research was a quantitative analytic observational study using cross-sectional design. The study was conducted in the work area of Wiyung Public Health Center, Surabaya. The population studied were mothers who had 7-12 month old babies in the work area of Wiyung Public Health Center, Surabaya. The subject studied were mothers who had 7-12 month old babies in the work area of Wiyung Public Health Center, Surabaya who met the inclusion criteria. The sample size of this study was obtained from calculations using Slovin formula with the value of $p=0.014$ from similar study is equal to 30 samples. ${ }^{10}$ Sampling technique used a purposive sampling method.

Criteria for inclusion in this study were mothers who had 7-12 month old babies in the work area of Wiyung Public Health Center, the subjects were willing to be the subject of the study and were able to answer questions verbally. The exclusion criteria in this study were mothers and babies who have contradictions in breastfeeding (e.g., HIV positive mothers without treatment, babies with galactosemia). ${ }^{11}$

This study obtained data from questionnaire by interviewing the subjects. The questionnaire used are made by the researcher.

The collected data will be tested using the Chi Square Fisher Exact statistical test with the help of SPSS software.

\section{Results}

Table 1. Characteristics of the subjects.

\begin{tabular}{cccc}
\hline Characteristics & Category & $\mathbf{n}$ & $\%$ \\
\hline Age (years) & $20-35$ & 27 & 90 \\
& $>35$ & 3 & 10 \\
\hline Workplace & Inside the house & 22 & 73.33 \\
& Outside the house & 8 & 26.67 \\
\hline Education & Junior high & 2 & 6.67 \\
& school/equal & & \\
& High school/equal & 11 & 36.67 \\
& Diploma & 2 & 6.67 \\
& Bachelor & 15 & 50 \\
\hline
\end{tabular}

In table 1 , most of all respondents $(90 \%)$ have an age range of 20 to 35 years old namely of 27 respondents, while respondents older than 35 years old are only 3 respondents $(10 \%)$. Most of the respondents do their jobs in the house (housewife and entrepreneur), namely 22 respondents (73.33\%). Furthermore, half $(50 \%)$ of all respondents had a bachelor degree as their last education namely 15 respondents, while the number of respondents with the last education in junior high school/equal and diploma was equal, namely each number only 2 respondents (6.67\%).

Table 2. Early initiation of breastfeeding.

\begin{tabular}{lcc}
\hline \multicolumn{1}{c}{ Category } & $\mathbf{n}$ & $\%$ \\
\hline $\begin{array}{l}\text { Perform early initiation of } \\
\text { breastfeeding }\end{array}$ & 16 & 53.33 \\
$\begin{array}{l}\text { Not perform early initiation of } \\
\text { breastfeeding }\end{array}$ & 14 & 46.67 \\
\hline
\end{tabular}

It can be seen from table 2 that more than half of the respondents namely 16 respondents (53.33\%) performed the early initiation of breastfeeding.

Table 3. Exclusive breastfeeding.

\begin{tabular}{lcc}
\hline \multicolumn{1}{c}{ Category } & $\mathbf{n}$ & $\%$ \\
\hline Give exclusive breastfeeding & 22 & 73.33 \\
Not give exclusive & 8 & 26.67 \\
breastfeeding & & \\
\hline
\end{tabular}

It can be seen from table 3 that most of all respondents namely 22 respondents (73.33\%) who performed the early initiation of breastfeeding succeed in giving exclusive breastfeeding.

Table 4. The relationship between early initiation of breastfeeding and exclusive breastfeeding for babies aged 712 months in the work area of Wiyung Public Health Center, Surabaya. 


\begin{tabular}{|c|c|c|c|c|c|c|c|}
\hline \multirow{3}{*}{$\begin{array}{l}\text { Early } \\
\text { initiati } \\
\text { on of } \\
\text { breastf } \\
\text { eeding }\end{array}$} & \multicolumn{4}{|c|}{$\begin{array}{l}\text { Exclusive } \\
\text { breastfeeding }\end{array}$} & \multirow{2}{*}{\multicolumn{2}{|c|}{ Total }} & \multirow[t]{3}{*}{$p$} \\
\hline & \multicolumn{2}{|c|}{ Yes } & \multicolumn{2}{|c|}{ No } & & & \\
\hline & $n$ & $\%$ & $\mathbf{n}$ & $\%$ & $\mathbf{n}$ & $\%$ & \\
\hline Yes & 12 & 40 & 4 & 13.33 & 16 & 53.33 & \\
\hline No & 10 & 33.33 & 4 & 13.33 & 14 & 46.67 & 0.574 \\
\hline Total & 22 & 73.33 & 8 & 26.67 & 30 & 100 & \\
\hline
\end{tabular}

In table 4 , there are 12 respondents (40\%) who did the early initiation of breastfeeding and succeed in giving exclusive breastfeeding, meanwhile there are 4 respondents $(13.33 \%)$ who did not do the early initiation of breastfeeding and did not succeed in giving exclusive breastfeeding.

Statistical analysis using Chi Square Fisher Exact Test with the help of SPSS Statistics 20 for Windows software obtained a value of $p=0.574$ with a value of $\alpha=0.05$. The value of $p>\alpha$ means that there is no relationship between early initiation of breastfeeding and exclusive breastfeeding in the work area of Wiyung Public Health Center in Surabaya.

\section{Discussion}

\section{Early Initiation of Breastfeeding}

Early initiation of breastfeeding is the process of breastfeeding the baby immediately after birth directly by placing the baby to the mother's chest for at least one hour until the baby finds the mother's nipple to suckle for the first time. ${ }^{7}$ In table 2 about the early initiation of breastfeeding, out of 30 respondents there are 16 respondents who did the early initiation of breastfeeding while 14 respondents did not do the early initiation of breastfeeding. This result means that more than half of all respondents in the work area of Wiyung Public Health Center, Surabaya already did the early initiation of breastfeeding with a percentage of $53.33 \%$. This number is higher than the national data in 2013 which showed that the percentage of early initiation of breastfeeding in Indonesia was $34.5 \%$, while the percentage of early initiation of breastfeeding in East Java was 33.3\%.

There has been an increase on early initiation of breastfeeding in Indonesia from $29.3 \%$ (2010) to $34.5 \%$ (2013). 6 One of the causes of this increase was the government's policy regarding early initiation of breastfeeding in 2012. The policy was contained in Government Regulation number 32 of 2012 concerning exclusive breastfeeding, explanation of early initiation of breastfeeding in articles 9 and 10. In article 9 verse 1 it is written that health workers and providers of health service facilities must initiate early breastfeeding of newborn babies to their mothers for a minimum of 1 (one) hour. ${ }^{12}$ Therefore, according to Wiyung Public Health Center officers, early initiation of breastfeeding is always done if the patient gives birth at the Wiyung Public Health Center, as long as the mother and the baby have no contraindications for early initiation of breastfeeding. This can be the reason for the high percentage of early initiation of breastfeeding in the results of this study.

\section{Exclusive breastfeeding}

Exclusive breastfeeding means the baby only consume breast milk as source of nutrition except medicines, vitamins, and mineral drops for 6 months after birth. ${ }^{2}$ The baby only receives nutritional sources in the form of breast milk per birth until the age of 6 months, without the addition of other fluids and solid foods.

The percentage of exclusive breastfeeding in Indonesia is $52.3 \%$, while the percentage of exclusive breastfeeding in East Java is $74 \% .^{2}$ Even though there has been an increase in the percentage of exclusive breastfeeding, this is still far from the national target on exclusive breastfeeding (80\%). Based on the results of this study, out of 30 respondents, there were 22 respondents (73.33\%) succeed in giving exclusive breastfeeding, meanwhile only 8 respondents $(26,67 \%)$ did not succeed in giving exclusive breastfeeding. This result means that more than half of all respondents in the work area of Wiyung Public Health Center, Surabaya already succeed in giving exclusive breastfeeding with a percentage of $73.33 \%$.

This number is lower than the percentage of exclusive breastfeeding in East Java. This might happen because there are many working mothers in Surabaya compared to mothers outside the city of Surabaya in the province of East Java. East Java is one of the provinces that has good exclusive breastfeeding rates because the percentage of exclusive breastfeeding in East Java is better than the national percentage. ${ }^{2}$ This might be the reason for the high percentage of exclusive breastfeeding in the results of this study that located in East Java.

The Relationship between Early Initiation of Breastfeeding and Exclusive Breastfeeding for Babies aged 7-12 months in the Work Area of Wiyung Public Health Center, Surabaya

In table 4 , most of the respondents (75\%) who did the early initiation of breastfeeding succeed in giving exclusive breastfeeding, meanwhile 4 respondents (25\%) did not succeed in giving exclusive breastfeeding although they have done the early initiation of breastfeeding before. Furthermore, from 14 respondents (46.67\%) who did not do the early initiation of breastfeeding, 10 respondents succeed in giving exclusive breastfeeding and only 4 respondents did not succeed in giving exclusive breastfeeding.

The independent variable in this study is early initiation of breastfeeding, while exclusive breastfeeding is the dependent variable. The value of $p=0.574$ with the value of $\alpha=0.05$ means that there is no relationship between early initiation of breastfeeding and exclusive breastfeeding in the work area of Wiyung Public Health Center in Surabaya.

With the absence of a relationship between the early initiation of breastfeeding and exclusive breastfeeding in this study, early initiation of breastfeeding is not the only factor that affects exclusive breastfeeding in babies aged 7-12 months in the work area of Wiyung Public Health Center in Surabaya. Other factors such as mother's knowledge, mother's job, mother's last education, and husband's behavior may also affect the succeed in giving exclusive breastfeeding. ${ }^{13-18}$ 


\section{Conclusion}

The value of $p=0.574$ with the value of $\alpha=0.05$ means that there is no relationship between early initiation of breastfeeding and exclusive breastfeeding in the work area of Wiyung Public Health Center in Surabaya. The early initiation of breastfeeding is not the only factor influencing exclusive breastfeeding for babies aged 7-12 months in the work area of Wiyung Public Health Center in Surabaya. Further research is needed on other factors such as mother's knowledge, mother's job, mother's last education, and husband's behavior that can relate to and influence exclusive breastfeeding.

\section{CONFLICT OF INTEREST}

The author stated there is no conflict of interest in this study.

\section{REFERENCES}

1.Indonesia KKR. Banyak Sekali Manfaat Asi Bagi Bayi dan Ibu Jakarta: Pusat Komunikasi Publik, Sekretariat Jenderal Kementerian Kesehatan Republik Indonesia, 2011.

2.Indonesia KKR. Profil Kesehatan Indonesia Tahun 2014. Jakarta: Kementerian Kesehatan Republik Indonesia, 2015.

3.Indonesia KKR. Dukung Ibu Bekerja Beri Asi Eksklusif. Jakarta: Pusat Komunikasi Publik Sekretariat Jenderal Kementerian Kesehatan Republik Indonesia, 2015.

4.Indonesia KKR. Situasi dan Analisis Asi Eksklusif. In: Indonesia KKR, (Ed.). Infodatin. Jakarta Selatan: Pusat Data dan Informasi Kementerian Kesehatan Republik Indonesia, 2014.

5.Roesli U. Inisiasi Menyusu Dini Plus Asi Eksklusif. Jakarta: Pustaka Bunda, 2008.

6.Trihono. Riset Kesehatan Dasar 2013. Jakarta: Badan Penelitian dan Pengembangan Kesehatan Kementerian Kesehatan Republik Indonesia, 2013.

7.Agusvina R. Hubungan Inisiasi Menyusu Dini (Imd) Terhadap Keberhasilan Asi Eksklusif di Posyandu Kelurahan Cempaka Putih Ciputat Timur. Jakarta: Univestas Islam Negeri Syarif Hidayatullah, 2015.

8.Fikawati $S$ and Syafiq A. Hubungan Antara Menyusui Segera (Immediate Breastfeeding) dan Pemberian Asi Eksklusif sampai dengan Empat Bulan. Jurnal Kedokteran Trisakti. 2003; 22.

9.Dinartiana and Sumini. Hubungan Pelaksanaan Inisiasi Menyusu Dini dengan Keberhasilan Pemberian Asi Eksklusif pada lbu yang Mempunyai Bayi Usia 7-12 Bulan di Kota Semarang. Dinamika Kebidanan. 2011; 1.

10.Ekaristi K and Mayulu. Hubungan Inisiasi Menyusu Dini dengan Pemberian Asi Eksklusif di Kota Manado. Kesmas. $2017 ; 6$.

11.Johnston M, Landers S, Noble L, Szucs K and Viehmann L. Breastfeeding and the Use of Human Milk. Pediatrics. 2012; 129: E827-41.

12.Indonesia Pr. Peraturan Pemerintah No. 33 Tahun 2012 tentang Pemberian Air Susu lbu Eksklusif. Jakarta: Lembaga Negara Republik Indonesia Tahun 2012, 2012.

13.Wijayanti W. Hubungan Antara Pemberian Asi Eksklusif dengan Angka Kejadian Diare pada Bayi Umur 0-6 Bulan di Puskesmas Gilingan Kecamatan Banjarsari Surakarta. Surakarta: Universitas Sebelas Maret Surakarta, 2010.

14.Zama M. Beberapa Faktor yang Berkaitan dengan Pola Pemberian Asi Eksklusif (Studi Kasus di Kelurahan Moru Kecamatan Moru Kabupaten Alor Propinsi Nusa Tenggara Timur. Surabaya: Universitas Airlangga, 2006.
15.Zulaikhah S. Faktor-faktor yang Berhubungan dengan Pemberian Asi Eksklusif di Kecamatan Sumowono Kabupaten Semarang Tahun 2010. Semarang: Universitas Negeri Semarang, 2010.

16.Putri Ay. Hubungan Pekerjaan Ibu dengan Keberhasilan Pemberian Asi Eksklusif pada Anak di Posyandu Bina Putra Tirto Triharjo Pandak Bantul Yogyakarta. Yogyakarta: Sekolah Tinggi IImu Kesehatan 'Aisyiyah Yogyakarta, 2014.

17.Ramadani $M$ and Hadi En. Dukungan Suami dalam Pemberian Asi Eksklusif di Wilayah Kerja Puskesmas Air Tawar Kota Padang, Sumatera Barat. 2010. 2010: 6.

18.Garbhani Aaih and Padmiari lae. Faktor-faktor yang Mempengaruhi Keberhasilan Pemberian Asi Eksksklusif Di Wilayah Kerja Puskesmas I Denpasar Timur. Virgin: Jurnal IImiah Kesehatan Dan Sains. 2015; 1. 